\title{
Effect of Bacillus aryabhattai on the initial establishment of pre-sprouted seedlings of
} sugarcane varieties

\author{
Efeito do Bacillus aryabhatai no estabelecimento inicial de mudas pré-brotadas de variedades de \\ cana-de-açúcar
}

Efecto de Bacillus aryabhatai en el establecimiento inicial de plántulas prebrotadas de variedades de caña de azúcar

Received: 01/25/2021 | Reviewed: 01/26/2021 | Accept: 01/29/2021 | Published: 02/07/2021

\author{
André May \\ ORCID: https://orcid.org/0000-0001-6157-7215 \\ Empresa Brasileira de Pesquisa Agropecuária Meio Ambiente, Brasil \\ E-mail: andre.may@embrapa.br \\ Michelli de Souza dos Santos \\ ORCID: https://orcid.org/0000-0002-9216-7363 \\ Empresa Brasileira de Pesquisa Agropecuária Meio Ambiente, Brasil \\ E-mail: michellisantos30@hotmail.com \\ Evandro Henrique Figueiredo Moura da Silva \\ ORCID: https://orcid.org/0000-0002-0913-8140 \\ Universidade de São Paulo, Brasil \\ E-mail: ehfmsilva@usp.br \\ Ronaldo da Silva Viana \\ ORCID: https://orcid.org/0000-0001-6819-5092 \\ Universidade Estadual Paulista, Brasil \\ E-mail: ronaldo@dracena.unesp.br \\ Nilson Aparecido Vieira Junior \\ ORCID: https://orcid.org/0000-0002-5651-5893 \\ Universidade de São Paulo, Brasil \\ E-mail: nilsonvieirajunior@usp.br \\ Nilza Patrícia Ramos \\ ORCID: https://orcid.org/0000-0002-9868-7722 \\ Empresa Brasileira de Pesquisa Agropecuária Meio Ambiente, Brasil \\ E-mail: nilza.ramos@embrapa.br \\ Itamar Soares de Melo \\ ORCID: https://orcid.org/0000-0003-2785-6725 \\ Empresa Brasileira de Pesquisa Agropecuária Meio Ambiente, Brasil \\ E-mail: itamar.melo@embrapa.br
}

\begin{abstract}
This study proposes to examine the potential use of Bacillus aryabhattai in pre-sprouted seedlings of sugarcane inoculated with the microorganism when subjected to different regimes of water supply after transplanting. The experiment was laid out in a randomized-block design with a complete $3 \times 2 \times 5$ factorial arrangement, in five replicates. The factors were represented by pre-sprouted seedlings of three sugarcane varieties (IAC 911099, RB 855156 and CTC 20 ), two seedling types (inoculated and not inoculated with $B$. aryabhattai) and five frequencies of water supply, which provided the ability of return to $100 \%$ soil field capacity, at every 0,10, 20,30 and 40 days. Plant mortality, plant height, number of leaves, stalk diameter and number of tillers were evaluated throughout the experimental period. At the end of the study, the shoot dry matter (SDM) and root dry matter (RDM) contents of the plants were measured. The number of leaves on the plant was affected only in isolation, according to the cultivar, without effects of the other studied factors. There was a double interaction effect between the factors of variety and inoculation $\left(\mathrm{V}^{*} \mathrm{I}\right)$ for the variables of SDM, stalk diameter and height; and between frequency and inoculation $\left(\mathrm{F}^{*} \mathrm{I}\right)$ for stalk diameter. There was a triple interaction effect between variety, inoculation and frequency $\left(\mathrm{V}^{*} \mathrm{I}^{*} \mathrm{~F}\right)$ for the RDM variable. Thus, the use of $B$. aryabhattai as an inoculant in pre-sprouted seedlings of sugarcane at the time of seedling formation can improve plant development after transplanting depending on the cultivar used, especially in IAC 911099 and RB 855156.
\end{abstract}

Keywords: Seedlings; Saccharum officinarum L.; Biological active ingredient; Inoculation.

\section{Resumo}

O objetivo do estudo foi avaliar o potencial de uso de Bacillus ariabhatai em mudas pré-brotadas de cana-de-açúcar inoculadas com o microrganismo, quando submetidas a diferentes regimes de fornecimento de água após transplantio 
O experimento foi conduzido utilizando um delineamento experimental em blocos casualizados, em esquema fatorial completo 3 × 2 x 5, com 5 repetições. Sendo compostos por mudas pré-brotadas de 3 variedades de cana (IAC 911099; RB 855156 e CTC 20) em 2 tipos de mudas (inoculadas e não inoculadas com $B$. aryabhatai) e 5 frequências de fornecimento de água, que estabeleciam voltar a capacidade de campo do solo para 100\% a cada 0, 10, 20, 30 e 40 dias. Ao longo do período experimental foram avaliadas: mortalidade de plantas, altura da planta, número de folhas, diâmetro do colmo e número de perfilhos. Ao final da pesquisa foram mensuradas a massa seca da parte aérea (MSPA) e a massa seca de raízes (MSR) das plantas. A característica número de folhas da planta foi afetada apenas isoladamente, conforme a cultivar, sem efeitos dos demais fatores estudados. Houve interação dupla entre os fatores: variedade e inoculação $\left(\mathrm{V}^{*} \mathrm{I}\right)$ para as variáveis MSPA, diâmetro e altura do colmo; e entre frequência e inoculação (F*I) para a característica diâmetro do colmo. Observou-se interação tripla entre variedade, inoculação e frequência $\left(\mathrm{V}^{*} \mathrm{I}^{*} \mathrm{~F}\right)$ para a variável MSR. Assim, pode-se concluir que o uso de B. aryabhattai como inoculante de mudas pré-brotadas de cana-de-açucar no momento de formação das mudas pode melhorar o desenvolvimento das plantas após transplantio, conforme a cultivar utilizada, principalmente IAC 911099 e RB 855156.

Palavras-chave: Mudas; Saccharum officinarum L; Ativo biológico; Inoculação.

\section{Resumen}

El objetivo del estudio fue evaluar el uso potencial de Bacillus ariabhatai en plántulas de caña de azúcar pre brotadas inoculadas con el microorganismo, además de ser sometidas a diferentes regímenes de suministro de agua después del trasplante. El experimento se realizó mediante un diseño experimental de bloques al azar, en un esquema factorial completo 3 × 2 × 5, con 5 repeticiones. Fue compuesto por plántulas pre brotadas de 3 variedades de caña (IAC 911099; RB 855156 y CTC 20) en 2 tipos de plántulas (inoculadas y no inoculadas con B. aryabhatai) y 5 frecuencias de suministro de agua, lo que establece un retorno a capacidad de campo del 100\% cada 0, 10, 20, 30 y 40 días. Durante el período experimental se evaluó la mortalidad de las plantas, la altura de las plantas, el número de plantas, el diámetro de la planta y el número de plantas. Al final del estudio, se medió la masa seca de la parte aérea (MSPA) y la masa seca de raíces (MSR) de las plantas. El número característico de plantas en la actualidad ha afectado al suelo de forma aislada, dependiendo del cultivo, sin los efectos de otros factores estudiados. Una doble interacción entre factores: variedad e inoculación $(\mathrm{V} * \mathrm{I})$ para las variables MSPA, diámetro y altura; y entre frecuencia e inoculación $(\mathrm{F} * \mathrm{I})$ para el diámetro característico del tallo. Tengo una triple interacción entre variedad, inoculación y frecuencia $(\mathrm{V} * \mathrm{I} * \mathrm{~F})$ para la variable MSR. Por tanto, se puede concluir que el uso de B. aryabhattai como inoculante de plántulas de caña de azúcar pre brotadas en el momento de la formación de plántulas podría mejorar el desarrollo de la planta después del trasplante, según el cultivar utilizado, principalmente IAC 911099 y RB 855156.

Palabras clave: Plántulas; Saccharum officinarum L.; Activo biológico; Inoculación.

\section{Introduction}

In the current scenario, Brazil is considered the largest sugarcane producer worldwide, with approximately 642 million tons processed in the 2019/2020 harvest (UNICA, 2020). The Brazilian sugarcane crop has grown significantly in recent decades, due mainly to investment in research. The country has become a world reference in technology for sugar and alcohol production (Oliveira et al., 2012).

At present, the sugarcane crop has demanded high levels of investment upon the establishment of the cane field, especially when the pre-sprouted seedling propagation technique is applied (Gazola et al., 2017). The use of bacterial inoculants can be an alternative to render this crop more sustainable (Lesueur et al., 2016). Studies show the benefits of using plant growthpromoting rhizobacteria (PGPR) in sugarcane, when aiming to improve plant development (Oliveira et al., 2006; Schultz et al., 2012).

Sugarcane seedlings inoculated with bacteria of the genus Enterobacter showed an increase in root and shoot dry matter (Mirza et al., 2001). On the other hand, the Bacillus aryabhattai strain CMAA 1363 was able to provide tolerance to the water deficit in maize plants (Kavamura et al., 2013) and to increase the root biomass production in some sugarcane varieties (Santos et al., 2017).

The effects of PGPR — especially those of the genus Bacillus — on plant development are broad, and these include beneficial effects on the promotion of plant emergence and growth (Schisler et al., 2004) or antagonism to phytopathogenic fungi (Araújo et al., 2005). Araújo and Hungria (1999) concluded that B. subtilis (AP-3) or its metabolites increased soybean nodulation and yield in the field, this strain being considered a producer of plant hormones and antibiotics (Araújo et al., 2005). 
In the maize crop, inoculation of seeds with Azospirillum significantly increased grain yield, confirming the positive effect of rhizobacteria on plants of this species (Cavallet et al., 2000). According to May et al. (2019), the inoculation of pre-sprouted seedlings of sugarcane cultivars IAC 911099 and RB 855156 with the bacterium B. aryabhattai improves shoot and root development, especially under water deficit.

Therefore, the present study was carried out examine the potential of the biological active ingredient Bacillus aryabhattai in the establishment of pre-sprouted seedlings of sugarcane varieties at different irrigation frequencies after transplanting.

\section{Methodology}

The study consists of an exploratory and descriptive greenhouse research with experimental design and quantitative nature, according to the characterization of Pereira et al. (2018). The experiment was conducted in a greenhouse in the experimental area of Embrapa Meio Ambiente, located in the municipality of Jaguariúna - SP, Brazil. A randomized-block design with a complete $3 \times 2 \times 5$ factorial arrangement was used in five replicates. Being the first factor composed of pre-sprouted seedlings of three varieties of sugarcane (IAC 911099, RB 855156 and CTC 20), the second for two seedling types (inoculated and not inoculated with Bacillus aryabhattai) and the third for the five frequencies of water supply, which provided the ability of return to $100 \%$ soil field capacity, namely, at every $0,10,20,30$ and 40 days.

The seedlings were formed in plastic trays using the propagation technique of mini-stumps containing a sugarcane bud, in substrate based on pine bark, followed by transplanting to 5-L pots with calcareous soil after 40 days. Training was carried out during the 80-day experimental period. The soil used originated from the same experimental location, which was classified as a dystric Red-Yellow Oxisol with clayey texture. The physicochemical characteristics of this soil, in the 0-20 cm layer, are as follows: $77 \mathrm{~g} \mathrm{~kg}^{-1}$ clay; $\mathrm{pH}\left(\mathrm{H}_{2} \mathrm{O}\right)=5.1 ; \mathrm{P}=24.2 \mathrm{mg} \mathrm{dm}^{-3} ; \mathrm{K}^{+}=3.6 \mathrm{mmolc} \mathrm{dm}{ }^{-3} ; \mathrm{Ca}^{2+}=45.6 \mathrm{mmolc} \mathrm{dm}{ }^{-3} ; \mathrm{Mg}^{2+}=22.8 \mathrm{mmolc}$ $\mathrm{dm}^{-3} ;$ and organic matter $=38.6 \mathrm{~g} \mathrm{~kg}^{-1}$.

The seedlings were inoculated with $B$. aryabhattai through biweekly foliar applications throughout the seedling production period, using a $10^{8}$ concentrated bacterial solution. Bacillus aryabhattai was isolated from bacteria associated with cacti from the Brazilian semi-arid region (Kavamura et al., 2013). The isolate is deposited in the microorganism collection of the Environmental Microbiology Laboratory (LMA) of Embrapa Meio Ambiente, under the code CMAA 1363 (https://www.ncbi.nlm. nih.gov/pmc/articles/PMC5289679/).

To form the bacterial solution of B. aryabhattai, the bacteria were multiplied in Petri dishes containing glucose culture medium and solidified yeast extract (GY), which were kept in a BOD incubator at $25^{\circ} \mathrm{C}$, for $24 \mathrm{~h}$. The bacterial colonies were transferred to the liquid GY culture medium and incubated for $72 \mathrm{~h}$, at $25^{\circ} \mathrm{C}$, in an orbital shaker, at $120 \mathrm{rpm}$. After this period, the material was centrifuged at $25{ }^{\circ} \mathrm{C}$ at $7000 \mathrm{rpm}$ for $15 \mathrm{~min}$ to form the pallets and the cell concentration was adjusted in a spectrophotometer to obtain $10^{8} \mathrm{CFU} \mathrm{mL}^{-1}$ of B. aryabhattai.

During the experimental period, the following traits were evaluated: plant mortality, plant height, number of leaves, stalk diameter and number of tillers. At the end of the study, shoot dry matter (SDM) and root dry matter (RDM) were measured.

Analysis of variance (ANOVA) and Tukey's test of means $(\mathrm{p}<0.01)$ were performed to evaluate the means obtained with the studied treatments.

\section{Results and Discussion}

Analysis of variance revealed a significant isolated effect of the variety factor for number of leaves. There was a double interaction effect between variety and inoculation $(\mathrm{V} * \mathrm{I})$ for SDM, stalk diameter and stalk height; and between frequency of 
water supply and inoculation $\left(\mathrm{F}^{*} \mathrm{I}\right)$ for stalk diameter. There was a triple interaction between variety, inoculation and frequency $(\mathrm{V} * \mathrm{I}$ F) for RDM (Table 1).

Table 1. Analysis of variance for the traits of stalk height, number of leaves, stalk diameter, shoot dry matter and root dry matter, considering the interaction between the factors of variety $(\mathrm{V})$, frequency of water supply $(\mathrm{F})$ and inoculation (I), in presprouted seedlings of sugarcane.

\begin{tabular}{lcccccccc}
\hline \multirow{2}{*}{ Trait } & \multicolumn{7}{c}{$\mathrm{p}$-value } \\
\cline { 2 - 9 } & $\mathrm{CV}(\%)$ & $\mathrm{V}$ & $\mathrm{F}$ & $\mathrm{I}$ & $\mathrm{V} * \mathrm{~F}$ & $\mathrm{~F} * \mathrm{I}$ & $\mathrm{V} * \mathrm{I}$ & $\mathrm{F} * \mathrm{I}^{*} \mathrm{~V}$ \\
\hline Stalk height & 15.39 & 0.0646 & 0.3659 & 0.4888 & 0.8109 & 0.7989 & 0.0076 & 0.7102 \\
Number of leaves & 15.66 & 0.0133 & 0.3111 & 0.2519 & 0.6020 & 0.0743 & 0.5399 & 0.2945 \\
Stalk diameter & 20.17 & 0.0003 & 0.0017 & 0.2798 & 0.9628 & 0.0098 & 0.0167 & 0.5308 \\
Shoot dry matter & 22.62 & 0.0194 & $<.0001$ & 0.3448 & 0.3894 & 0.8925 & 0.0399 & 0.3688 \\
Root dry matter & 29.91 & $<.0001$ & $<.0001$ & 0.0377 & $<.0001$ & 0.0003 & 0.0001 & 0.0003 \\
\hline
\end{tabular}

Source: Authors.

The RB 855156 variety had a higher average number of leaves than CTC 20, whereas IAC 911099 did not differ from either (Table 2). This trait may be related to the genetic material used, as there was no influence of the frequency of water supply or inoculation during the evaluated experimental period. Matoso et al. (2016) also found no influence of inoculation with several strains of bacteria on the number of leaves of varieties RB 966928, RB 867515, RB 966928 and RB 867515. The researchers attributed the difference in number of leaves to the genotype variation between the studied varieties.

Table 2. Number of leaves on the plant, in three sugarcane varieties: CTC 20, IAC 911099 and RB 855156.

\begin{tabular}{lc}
\hline Variety & $\begin{array}{c}\text { Number of } \\
\text { leaves }\end{array}$ \\
\hline IAC 911099 & $5.78 \mathrm{AB}$ \\
RB 855156 & $6.20 \mathrm{~A}$ \\
CTC 20 & $5.68 \mathrm{~B}$
\end{tabular}

Means followed by different letters differ from each other by Tukey's test $(\mathrm{p}<0.01)$.

Source: Authors.

In the analysis of the effect of inoculation on stalk diameter, no statistical difference was found between the water supply frequencies of every 10,20,30 and 40 days in the inoculated plants. However, stalk diameter was higher when the plants were inoculated and subjected to a test of extreme water deficiency ( 0 days: no water supply after transplanting). For the plants that did not receive inoculation with the bacterium, there was no difference between the means observed at the different water supply frequencies (Table 3). 
Table 3. Stalk diameter (in $\mathrm{cm}$ ) of inoculated and non-inoculated sugarcane plants using five frequencies of water supply: every $0,10,20,30$ and 40 days.

\begin{tabular}{lcc}
\hline Frequency & Inoculated & $\begin{array}{c}\text { Non- } \\
\text { inoculated }\end{array}$ \\
\hline 0 & $4.58 \mathrm{aA}$ & $3.94 \mathrm{bA}$ \\
10 & $3.56 \mathrm{aB}$ & $4.10 \mathrm{aA}$ \\
20 & $3.36 \mathrm{aB}$ & $3.65 \mathrm{aA}$ \\
30 & $3.73 \mathrm{aB}$ & $3.38 \mathrm{aA}$ \\
40 & $4.04 \mathrm{aAB}$ & $3.52 \mathrm{aA}$ \\
\hline
\end{tabular}

Means followed by uppercase letters compare with each other in the columns, and those followed by lowercase letters compare with each other in the rows, by Tukey' test $(\mathrm{p}<0.01)$.

Source: Authors.

Inoculation of pre-sprouted sugarcane seedlings with $B$. aryabhattai promoted an increase in stalk diameter in the studied varieties when they were exposed to the maximum water deficit, i.e., the water supply frequency of 0 days. May et al. (2019) evaluated the effect of inoculation with B. aryabhattai on the induction of tolerance to water deficit in varieties IAC 911099 and RB 855156 and observed that the inoculated seedlings had a thicker stalk in the 7- and 14-day irrigation intervals as compared with non-inoculated seedlings.

Table 4 shows the performance of pre-sprouted seedlings of sugarcane varieties IAC 911099, RB 855156 and CTC 20 for the traits of stalk height, stalk diameter and SDM. In terms of stalk height, there was a positive effect of inoculation with $B$. aryabhattai for the RB 855156 variety, whereas varieties IAC 911099 and CTC 20 exhibited no significant influence of this factor. The CTC 20 variety had the smallest diameter among the varieties. There was a positive effect of inoculation for variety IAC 911099, with the inoculated seedlings having a larger stalk diameter. Inoculation of the plants with the bacterium did not improve the expression of SDM, due to the greater development of the root system, as shown in Tables 5 and 6 , mainly for varieties IAC 911099 and RB 855156. 
Table 4. Stalk height, stalk diameter and shoot dry matter responses in pre-sprouted seedlings of sugarcane as a function of the factors of variety (IAC 911099, RB 855156 and CTC 20) and inoculation (with and without).

\begin{tabular}{|c|c|c|}
\hline \multirow{2}{*}{ Variety } & \multicolumn{2}{|c|}{ Inoculation } \\
\hline & With & Without \\
\hline \multicolumn{3}{|c|}{ Stalk height $(\mathrm{cm})$} \\
\hline IAC 911099 & $12.93 \mathrm{aA}$ & $13.82 \mathrm{aA}$ \\
\hline RB 855156 & $13.33 \mathrm{aA}$ & $11.70 \mathrm{bB}$ \\
\hline CTC 20 & $13.27 \mathrm{aA}$ & $13.32 \mathrm{aA}$ \\
\hline \multicolumn{3}{|c|}{ Stalk diameter $(\mathrm{cm})$} \\
\hline IAC 911099 & $4.27 \mathrm{aA}$ & $3.79 \mathrm{bA}$ \\
\hline RB 855156 & $4.05 \mathrm{aA}$ & $3.76 \mathrm{aA}$ \\
\hline CTC 20 & $3.24 \mathrm{aB}$ & $3.61 \mathrm{aA}$ \\
\hline \multicolumn{3}{|c|}{ Shoot dry matter (g) } \\
\hline IAC 911099 & $1.02 \mathrm{aB}$ & $1.47 \mathrm{aB}$ \\
\hline RB 855156 & $4.82 \mathrm{bA}$ & $5.68 \mathrm{aA}$ \\
\hline CTC 20 & $1.15 \mathrm{aB}$ & $1.05 \mathrm{aB}$ \\
\hline
\end{tabular}

Means followed by uppercase letters compare with each other in the columns, and those followed by lowercase letters compare with each other in the rows, by Tukey' test $(\mathrm{p}<0.01)$.

Source: Authors.

The action of some bacteria as growth regulators can inhibit plant growth, depending on the concentration applied (Spaepen et al., 2007). This may explain the lower SDM production of variety RB 855156 inoculated by B. aryabhattai. Santos et al. (2019) described similar results, with the inoculation of Paraburkholderia tropica and Nitrospirillum amazonense in sugarcane variety IACSP 955000 impairing plant growth, which was possibly due to some hormonal stress.

In this respect, it is important to note that different sugarcane varieties can have different responses when inoculated by different strains of bacteria, as influenced by the interaction between the microorganisms and the genotype of these tested plants (Oliveira et al., 2006). Chaves et al. (2015) studied the initial development of sugarcane varieties RB 867515 and IACSP 955000 inoculated with diazotrophic bacteria and found differences in shoot/root ratio in either variety. The inoculated IAC SP 955000 variety showed an increase in RDM production whereas variety RB 867515 showed greater development of the aerial part. 
When inoculated with B. aryabhattai, variety IAC 911099 exhibited the best RDM production performance among the studied genetic materials, obtaining the highest mean at the water supply frequency of every 10 days. Likewise, for the other studied cultivars, the frequency of every 10 days provided the best performance for the RDM trait (Table 5).

Table 5. Root dry matter response in pre-sprouted seedlings of sugarcane inoculated with $B$. aryabhattai as a function of the factors of variety and frequency of water supply.

\begin{tabular}{lccc}
\hline \multirow{2}{*}{ Frequency } & \multicolumn{3}{c}{ Variety } \\
\cline { 2 - 4 } & CTC 20 & IAC 911099 & RB 855156 \\
\hline 0 & $0.49 \mathrm{aB}$ & $0.41 \mathrm{aB}$ & $0.31 \mathrm{aB}$ \\
10 & $1.21 \mathrm{bA}$ & $2.04 \mathrm{aA}$ & $1.46 \mathrm{bA}$ \\
20 & $0.32 \mathrm{aB}$ & $0.25 \mathrm{aB}$ & $0.29 \mathrm{aB}$ \\
30 & $0.32 \mathrm{aB}$ & $0.44 \mathrm{aB}$ & $0.31 \mathrm{aB}$ \\
40 & $0.49 \mathrm{aB}$ & $0.46 \mathrm{aB}$ & $0.32 \mathrm{aB}$ \\
\hline
\end{tabular}

Means followed by uppercase letters compare with each other in the columns, and those followed by lowercase letters compare with each other in the rows, by Tukey' test $(\mathrm{p}<0.01)$.

Source: Authors.

Table 6 shows the performance of non-inoculated pre-sprouted seedlings of sugarcane varieties IAC 911099, RB 855156 and CTC 20 for RDM as a function of the factors of inoculation and water supply. In the absence of inoculation, the highest means were also obtained at the water supply frequency of every 10 days, and RB 855156 exhibited the lowest RDM production among the studied varieties (Table 6).

Table 6. Root dry matter response in pre-sprouted seedlings of sugarcane not inoculated with B. aryabhattai as a function of the factors of variety and frequency of water supply.

\begin{tabular}{lllc}
\hline \multirow{2}{*}{ Frequency } & \multicolumn{3}{c}{ Variety } \\
\cline { 2 - 4 } & CTC 20 & IAC 911099 & RB 855156 \\
\hline 0 & $0.37 \mathrm{aB}$ & $0.31 \mathrm{aB}$ & $0.35 \mathrm{aB}$ \\
10 & $1.48 \mathrm{aA}$ & $1.40 \mathrm{aA}$ & $0.92 \mathrm{bA}$ \\
20 & $0.33 \mathrm{aB}$ & $0.25 \mathrm{aB}$ & $0.26 \mathrm{aB}$ \\
30 & $0.63 \mathrm{aB}$ & $0.45 \mathrm{abB}$ & $0.31 \mathrm{bB}$ \\
40 & $0.62 \mathrm{aB}$ & $0.41 \mathrm{aB}$ & $0.14 \mathrm{bB}$ \\
\hline
\end{tabular}

Means followed by uppercase letters compare with each other in the columns, and those followed by lowercase letters compare with each other in the rows, by Tukey' test $(\mathrm{p}<0.01)$.

Source: Authors.

When not inoculated, the RB 855156 variety had the lowest RDM means among the evaluated varieties at the water supply frequencies of every 10,30 and 40 days (Table 6). The analysis of the performance of seedlings of this variety inoculated with B. aryabhattai revealed no statistical differences in relation to varieties IAC 911099 and CTC 20 at the water supply frequencies of 30 and 40 days (Table 5). Growth regulators produced by various microorganisms, including bacteria, can act on the development of lateral and adventitious roots, cell division and root and stalk elongation through specific phytohormones such as auxins, cytokinins, gibberellins and ethylenes (Cassán et al., 2014). 
Many studies have described a positive effect of inoculation with B. aryabhattai on seedlings of other plant species, such as cabbage (Lee et al., 2018), maize (Ahmad et al., 2019) and raspberry (Orhan et al., 2006). These studies reported increased RDM production, stimulation to plant growth and, consequently, increased yield. These results can be explained by the ability of the bacterium B. aryabhattai to solubilize phosphate in the rhizosphere region, for instance (Nadeem et al., 2014).

Studies with pre-sprouted seedlings of sugarcane showed an increase in the RDM of varieties RB 867515 and IACSP 955000 when inoculated with diazotrophic bacteria (Santos et al., 2019) and for seedlings of variety IACSP 803280 inoculated with B. subtilis and B. licheniformis (Santos \& Rigobelo, 2016). Phytohormones produced by B. pumilus and B. subtilis can contribute greatly to improving plant development. Phytohormones are organic substances that can promote, inhibit or modify the growth and development of plants at low concentrations (Damam et al., 2016).

May et al. (2019), in turn, found that, in addition to favoring root development, inoculation of variety IAC 911099 with $B$. aryabhattai provided the seedlings with greater resistance to water deficit. In these studies, in the inoculated seedlings, RDM was approximately twice as high in the treatment with an irrigation interval of 21 days when compared with control, without inoculation with the bacterium.

Inoculation with rhizobacteria such as $B$. aryabhattai can mitigate the impacts suffered by plants exposed to drought. This occurs through chemical and biochemical changes within the plant or in the rhizosphere, which modifies the plant physiology and gives it tolerance to water deficit (Dimkpa et al., 2009). In this study, the inoculated plants of varieties IAC 91099 and RB 855156 showed a higher RDM in relation to non-inoculated plants under greater water restriction (frequency of water supply every 40 days). Thus, for these varieties, the greater development of the root system of the seedlings inoculated with $B$. aryabhattai can contribute to enhancing nutrient and water absorption by the plant and increasing drought tolerance in adverse growing conditions. This practice can have a direct impact on the formation of cane fields, reducing transplanting costs and increasing the crop yield.

\section{Conclusion}

The use of $B$. aryabhattai as an inoculant in pre-sprouted seedlings of sugarcane at the time of seedling formation can improve plant development after transplanting depending on the cultivar used, especially in IAC 911099 and RB 855156. New research must be carried out with other sugarcane cultivars, as there is a great variation in the response of the asset according to the genetic material used.

\section{References}

Ahmad, M., Adil, Z., Hussain, A., Mumtaz, M. Z., Nafees, M., Ahmad, I., \& Jamil, M. (2019). Potential of phosphate solubilizing Bacillus strains for improving growth and nutrient uptake in mungbean and maize crops. Pakistan Journal of Agricultural Sciences, 56(2).

Araújo, F. F. D., \& Hungria, M. (1999). Nodulação e rendimento de soja co-infectada com Bacillus subtilis e Bradyrhizobium japonicum/Bradyrhizobium elkanii. Pesquisa agropecuária brasileira, 34(9), 1633-1643.

Araujo, F. F., Henning, A. A., \& Hungria, M. (2005). Phytohormones and antibiotics produced by Bacillus subtilis and their effects on seed pathogenic fungi and on soybean root development. World Journal of Microbiology and Biotechnology, 21(8-9), 1639-1645.

Cassán, F., Vanderleyden, J., \& Spaepen, S. (2014). Physiological and agronomical aspects of phytohormone production by model plant-growth-promoting rhizobacteria (PGPR) belonging to the genus Azospirillum. Journal of Plant Growth Regulation, 33(2), 440-459.

Cavallet, L. E., Pessoa, A. C. D. S., Helmich, J. J., Helmich, P. R., \& Ost, C. F. (2000). Produtividade do milho em resposta à aplicação de nitrogênio e inoculação das sementes com Azospirillum spp. Revista Brasileira de Engenharia Agrícola e Ambiental, 4(1), 129-132.

Chaves, V. A., Santos, S. G. D., Schultz, N., Pereira, W., Sousa, J. S., Monteiro, R. C., \& Reis, V. M. (2015). Desenvolvimen to inicial de duas variedades de cana-de-açúcar inoculadas com bactérias diazotróficas. Revista Brasileira de Ciencia do solo, 39(6), 1595-1602.

Damam, M., Kaloori, K., Gaddam, B., \& Kausar, R. (2016). Plant growth promoting substances (phytohormones) produced by rhizobacterial strains isolated from the rhizosphere of medicinal plants. International Journal of Pharmaceutical Sciences Review and Research, 37(1), 130-136. 
Dimkpa, C., Weinand, T., \& Asch, F. (2009). Plant-rhizobacteria interactions alleviate abiotic stress conditions.Plant, cell \& environment, 32 (12), $1682-1694$.

Gazola, T., Cipola Filho, M. L., \& Júnior, N. C. F. (2017). Avaliação de mudas pré-brotadas de cana-de-açúcar provenientes de substratos submetidos a adubação química e orgânica. Científica, 45(3), 300-306.

Kavamura, V. N., Santos, S. N., da Silva, J. L., Parma, M. M., Ávila, L. A., Visconti, A., \& de Melo, I. S. (2013). Screening of Brazilian cacti rhizobacteria for plant growth promotion under drought. Microbiological research, 168(4), 183-191.

Lee, Y. H., Jang, S. J., Han, J. H., Bae, J. S., Shin, H., Park, H. J. \& Hong, J. K. (2018). Enhanced Tolerance of Chinese Cabbage Seedlings Mediated by Bacillus aryabhattai H26-2 and B. siamensis H30-3 against High Temperature Stress and Fungal Infections. The Plant Pathology Journal, $34(6), 555$.

Lesueur, D., Deaker, R., Herrmann, L., Bräu, L., \& Jansa, J. (2016). The production and potential of biofertilizers to improve crop yields. In Bioformulations: for sustainable agriculture (pp. 71-92). Springer, New Delhi.

Matoso, E. S., De Marco, E., Bellé, C., Rodrigues, T. A., \& dos Anjos, S. D. (2016). Desenvolvimento inicial de mudas pré-brotadas de cana-de-açúcar inoculadas com bactérias diazotróficas. Revista da Jornada de Pós-Graduação e Pesquisa-Congrega Urcamp, 412-434.

May, A., Ramos, N., Santos, M. D. S., da Silva, E. H. F. M., \& de Melo, I. S. (2019). Promoção de crescimento de mudas pré-brotadas de cana-de-açúcar inoculadas com Bacillus aryabhattai em diferentes frequências de irrigação. Embrapa Meio Ambiente-Boletim de Pesquisa e Desenvolvimento (INFOTECA-E).

Mirza, M. S., Ahmad, W., Latif, F., Haurat, J., Bally, R., Normand, P., \& Malik, K. A. (2001). Isolation, partial characterization, and the effect of plant growthpromoting bacteria (PGPB) on micro-propagated sugarcane in vitro. Plant and Soil, 237(1), 47-54.

Nadeem, S. M., Ahmad, M., Zahir, Z. A., Javaid, A., \& Ashraf, M. (2014). The role of mycorrhizae and plant growth promoting rhizobacteria (PGPR) in improving crop productivity under stressful environments. Biotechnology advances, 32(2), 429-448.

Oliveira, A. L. M., de Canuto, E. L., Urquiaga, S., Reis, V. M., \& Baldani, J. I. (2006). Yield of micropropagated sugarcane varieties in different soil types following inoculation with diazotrophic bacteria. Plant and Soil, 284(1-2), 23-32.

Oliveira, T. B. A., Selig, P. M., Barbosa, V. M., de Souza Campos, L. M., Bornia, A. C., \& de Oliveira, M. W. (2012). Tecnologia e custos de produção de canade-açúcar: um estudo de caso em uma propriedade agrícola. Latin American Journal of Business Management, 3(1).

Orhan, E., Esitken, A., Ercisli, S., Turan, M., \& Sahin, F. (2006). Effects of plant growth promoting rhizobacteria (PGPR) on yield, growth and nutrient contents in organically growing raspberry. Scientia Horticulturae, 111(1), 38-43.

Pereira A.S. et al. (2018). Metodologia da pesquisa científica. UAB/NTE/UFSM. https://repositorio.ufsm.br/bitstream/handle/1/15824/ Lic_Computacao_Metodologia-Pesquisa-Cientifica.pdf?sequence=1.

Santos, M. D. S., Stancatte, R. S., Ferreira, T. C., Dorighello, D. V., Pazianotto, R. A. A., de Melo, I. S., \& Ramos, N. P. (2017). Resistance to water deficit during the formation of sugarcane seedlings mediated by interaction with Bacillus sp. Científica, 45(4), 414-421.

Santos, R. D. \& Rigobelo, E. (2016). Uso de Bacillus subtilis e Bacillus licheniformis na promoção de crescimento de mudas pré-brotadas de cana-deaçúcar. Ciência \& Tecnologia: Fatec-JB, 8(especial).

Santos, S. G., Chaves, V. A., da Silva Ribeiro, F., Alves, G. C., \& Reis, V. M. (2019). Rooting and growth of pre-germinated sugarcane seedlings inoculated with diazotrophic bacteria. Applied Soil Ecology, 133, 12-23.

Schisler, D. A., Slininger, P. J., Behle, R. W., \& Jackson, M. A. (2004). Formulation of Bacillus spp. for biological control of plant diseases. Phytopathology, 94(11), 1267-1271.

Schultz, N., Morais, R. F. D., Silva, J. A. D., Baptista, R. B., Oliveira, R. P., Leite, J. M., \& Boddey, R. M. (2012). Avaliação agronômica de variedades de canade-açúcar inoculadas com bactérias diazotróficas e adubadas com nitrogênio. Pesquisa Agropecuária Brasileira, 47(2), 261-268.

Spaepen, S., Vanderleyden, J., \& Remans, R. (2007). Indole-3-acetic acid in microbial and microorganism-plant signaling.FEMS microbiology reviews, 31(4), $425-448$.

UNICA, (2020). União da indústria de cana-de-açúcar. https://www.unicadata.com.br/historico-deproducao-emoagem.php?idMn=32\&tipoHistorico =4. 